\title{
Bringing Potable Water to the Town, the Endeavour towards the Nagercoil Water Supply Scheme
}

\author{
Agney G K \\ Mar Thoma College, M G University, Thiruvalla, Kerala, India
}

Email: gkagni@gmail.com

Keywords: NAGERCOIL, MUKKADAL VALLEY, HUME STEEL PRESSURE PIPE.

\begin{abstract}
The paper resolves to chronicle the outlining of a water supply apparatus in the municipal town of Nagercoil in erstwhile princely state of Travancore. Nagercoil lies to the southern tip of the Republic of India and is a major city in the state of Tamilnadu. It was one of the most populous municipal towns in Travancore and faced acute shortage, because of the aridity caused by evasive monsoon and high population density, of potable water. The author desires to narrate the decisions adopted by the Government of $\mathrm{H} \mathrm{H}$ The Maharaja of Travancore ( $\mathrm{H} \mathrm{H}$ Stands for His Highness) with relation to the planning and execution of the various modalities related to the water supply scheme.
\end{abstract}

\section{Familiarizing}

Potable water is the paramount design to forestall the transmission of contagious diseases that causes havoc in a closely packed settlement. Unhygienic conditions and inadequacy of potable water has wrecked the orderly life of citizens in many modern (relating to the frame of study, i.e. $20^{\text {th }}$ century) cities. But Travancore was a misnomer to the aforesaid list. The government of the $\mathrm{H}$ $\mathrm{H}$ The Maharaja of Travancore ( $\mathrm{H} \mathrm{H}$ stands for His Highness) had taken all cardinal measures to ensure that his subjects are provided with the basic requirements for a healthy living- hygienic conditions, sanitation facilities and potable drinking water. Along with the town of Travancore, that was served by the monumental Willington water work, the other populous municipal towns like Alleppey; which had saline underground water, Shencotta and Nagercoil; both water starved regions, were served with well-functioning water management system. This paper deals with the endeavour and operations by the government to supply water to the town of Nagercoil, from 1935 till the commissioning of the scheme in 1937-38.

\section{Endeavour for water supply}

The insistence for a water supply scheme for the Mofussil town of Nagercoil was incipiently voiced during the 1920s, when a water supply scheme for the town of Travancore was under 
consideration. The below par rainfall and the droughts that occurred in succession from 1932 to 1935 accentuated the cry for a water supply mechanism for, this since time immemorial, drought prone area. The attempt to provide water supply scheme for Nagercoil was absolutely recognised when the government of $\mathrm{H} \mathrm{H}$ The Maharaja of Travancore in his proceedings of 1935 took up the issue of providing appreciable water supply to all municipal towns, Alleppey, Shencotta and Nagercoil, under his jurisdiction.

The Nagercoil scheme, of water supply, was modelled on the Willingdon water supply scheme of Trivandrum. It was prospected to construct an earthen dam, with a puddle core to prevent the leaching and leaking of the dam, across the Mukkadal valley about 8 miles north of the town. The dam was anticipated to hold 6.5 million cubic feet of drawable water, commensurate to a year's demand. The dam was outlined to be 1080 feet long, 20 feet wide at the top and 314 feet at the lowest ground level and 52 feet high above the lowest ground level. From there, it was planned, to gravitate the water to the town though a 16 inch Hume Steel Pressure Pipe gravitation main, of 7.5 miles length, to the purification plant located inside the town, which was expected to be of the rapid mechanical gravity description with the sufficient chemical dosage gizmos, coagulation tanks, filtration and sterilization plants. Hume pipes were used to allay the fears of fissures due to high pressure conceived of the immense chunk of water. The slenderness and tenacity of the Hume pipes was preferred over the popularity of Cast Iron (C.I) pipes.

A water service cistern designated as a balancing tank, to supply water to the low level zones of the town, was also recommended near the aforementioned structure. The High level areas were to be catered by an overhead tank erected at Ramavarmapuram, in the topmost part of the town. After purification, it was supposed; that the water would be pumped to $40 \%$ of the households, in the higher level of the town through twelve pumps, of centrifugal nature, housed at one end of the low level reservoir, and will be flowed to $60 \%$ of the houses using natural slope and gravity. For the aforementioned process the town was divided into two zones, Low Level and High Level. Further, the whole town was divided into nine water supply divisions, each division being furnished by its exclusive division main branching off from the trunk main. The design also encompassed structuring 360 street fountains, fitted with waste- not taps, to prevent the loss of "precious" water, to the whole town.

A survey on the capital cost of the scheme was undertaken by the Water Works and Drainage Engineer to the government of $\mathrm{H} \mathrm{H}$ The Maharaja of Travancore. After considering the scheme he provided a budget of sixteen lakhs for the scheme. The capital expenses were to be met with a government loan and it was decided that the municipal council will repay the loan, along with its interest, within a stipulated period, as agreed by the government of $\mathrm{H} \mathrm{H}$ The Maharaja of Travancore and that of the Municipality. Half of the expenditure for commissioning the water supply scheme was to be borne by the government of $\mathrm{H} \mathrm{H}$ The Maharaja of Travancore, as a financial grant and the rest was advanced to the municipality as a loan, for which the rate was fixed at $4.5 \%$ per annum. The loan was to be repaid in 35 years as equal instalments considering the financial health of the municipality. Thus of the 16 lakhs mentioned earlier, the Raja was to provide 8 lakhs as grant and 8 lakhs as loan. The municipality was indebted to make a payment of not less than Rs. 62,800 per annum for 35 years. The municipality was to collect Rs. 12,000 per annum on account of metering both the supply of water to the domestic and non-domestic purposes. The remaining amount was to be met through water tax. The water tax was to be levied on a neutral rate, without taking into consideration the particular consumption of individual users, at $8.5 \%$, which was much lower than that of Coimbatore. With the increase in the number of houses, the neutral 
value of tax was also to increase. But the interest and sinking fund charge were to be fixed and was not meant to be flexible.

It was also stipulated that the government of $\mathrm{H} \mathrm{H}$ The Maharaja of Travancore will cover the expenses for the yearly maintenance of the water supply apparatus for which simple interest would be calculated on the amount used and will later be added to the capital when the construction of the apparatus is over. Once the construction is over, it was deemed that any maintenance works, improvements or renewal or any work involving increased capital cost should be borne by the municipality, as the mechanism for water supply was to be deemed as the property of the municipality once the works are done.

Rao Bahadur M Nilakanta Iyer was tasked by the government of $\mathrm{H} \mathrm{H}$ The Maharaja of Travancore to report about the feasibility of a water supply scheme for the municipality of Nagercoil and suggest solutions for the water constrains faced. After elaborate, but ill-considered, study he prepared a report suggesting the sinking of wells as a panacea for the water constrains of the municipality. The proposal would have been considered absurd against the modern standards and if we consider the fact that the area under discussion is a water starved area and the period we are taking about is a period post 4 years of successive drought. The proposal thus submitted to the President of the Nagercoil municipal council proposes that enough water for the town could be obtained by sinking wells. His intention was to utilise the spring water beneath the laterite uplands of Nagercoil. He also reported that the system of wells not only, could, provide good and copious supply of water but also lay down the capital cost of the work which could be huge if the water was to be brought from Mukkadal through an eighty mile pipe. After considering the proposal one feels that the report was conceived with the sole purpose of allying the fears, of increase financial burden on the municipality as a part of escalating capital cost due to the Mukkadal schemes, at bay and provide for a transitory solution to the severe water crisis. The proposal was taken forward to the government of $\mathrm{H} \mathrm{H}$ The Maharaja of Travancore, and tests were conducted by the water works in some of the wells in Nagercoil town. But the result of the tests, which pointed out the enormous amount of biological and chemical pollutants in the water, led the government to the conclusion that the Mukkadal scheme was decidedly more advantageous and was to be preferred in respect to efficacy. Thus efficacy of the scheme was provided preference over the cost that was to be incurred. The vision and financial efficiency of the Maharaja can be gauged from the fact that though the government was under financial constrain because of the commissioning of the projects, of similar quantum, nature and scope, was progressing in four towns, Trivandrum, Alleppey, Shencotta and Nagercoil, of the kingdom and the government was the sole repository for all the schemes and only a part of the amount such rendered will be retuned that too only after 3 decades, still the proactive king decided in favour of creating a sustainable solution to the problem. The report of the water works in clear terms spoke against the well scheme, earlier, proposed by Iyer as not feasible, illconsidered and thus cannot be adopted. The proposal of Iyer also encompassed a proposal for supplying water only to public taps. Later it was raised as a discrepancy of the water supply scheme by the resident of the town and the scope of the scheme was later extended to include water supply to houses also. The Nagercoil municipal council in a subsequent amendment of the clause 1 of the draft agreement legislated that the water supply scheme shall besides the supply of water in public fountains or taps make provision for house connection also. Later, in a draft prepared by the water works and drainage engineer to the Government of Travancore it was stated that the water supply scheme shall not extend its scope to fire service and nondomestic purposes, but shall be confined to domestic purposes only. 
The scheme proposed to provide twelve gallons of water per day to each of its citizens and also resolved to yield four litres as supplementary during the summer season. Such was the foresightedness of the government that, though the apparatus was conceived in 1935, when the population of the town was 42,950 souls (as per the 1931 census report of the Government of Travancore) it aspired at administering water to a population of 77,800 (estimated population of 1971).

\section{Conclusion}

Erecting a water supply gizmo will feel miniscule when benchmarked against the modern standards. But the structure and scope of this scheme, of water supply to the town of Nagercoil, should be gauged and understood in the context of the $20^{\text {th }}$ century India. We are speaking of a time when the Cochin Princely State, that shared its boundary with Travancore, was deliberating in its legislative council about rationing water and creating public bathing Ghats to cater to the water needs of the citizens. The attempt to ration water and provide metered connections created rucks in the assembly. The provision to supply additional water to a household in case they held guests from other towns were discussed at length in the Cochin legislature. The scheme to supply water to the urban areas in the Cochin princely states, involved no supplementary grants, what the case may be. This was also a time when the colonial towns in South India like Coimbatore were levying exorbitant rates as water tax and discriminating over the provision of providing portable water. The canvas should also be broadened to encompass North India especially Delhi and her Sarais and how these towns and their water supply systems that had existed hitherto, were crumbled under the weight of mistargeted colonial architecture and 'adjustments'. Thus zeal and commitment to the cause of maintaining the public amenities, especially water supply apparatus in populous towns, of the government of The $\mathrm{H} \mathrm{H}$ Maharaja of Travancore should be read in the context of how limited the resources of a princely state under the British crown was and how the other Rajas and Governors faired.

\section{References}

[1] Pillai, Velu. (1940) Travancore State Manual Volume 3, Government of Travancore, $70-93$

[2] Pillai, Velu. (1940) Travancore State Manual Volume 4, Govt, of Travancore, 169-174

[3] Pillai, Velu. (1940) Travancore State Manual Volume 1, Govt, of Travancore, 1-85

[4] Sengupta, Pradip K (2017) Industrial Water Resource Management, Wiley, 262-268

[5] Planning Commission(1959) Kerala Development Report, Government of India

[6] Report (1966) Committee of Estimates, Govt. of Madras

[7] PWD Files, Bundle 494-496, Central Archives, Trivandrum, India.

[8] Proceedings of the Government of The H H Maharaja of Travancore 1932,1935,1936. 